\title{
THE ROLE OF THE COMMUNITY NURSE IN FAMILY HEALTH CARE
}

\author{
JO M.M. GODDARD \\ (R.N. R.M. O.N.C. DIP. N (PUBLIC HEALTH) UNIV. LOND.) \\ LECTURER IN COMMUNITY NURSING - TECHNIKON WITWATERSRAND
}

\section{OPSOMMING}

Die veld van die gemeenskapsverpleegkundige in gesinsorg sluit moeder- en kindergesondheid, beheer van aansteeklike siektes, skoolgesondheidsdienste, bedryfsgesondheid, gemeenskapspsigiatrie, bejaardesorg en gesondheidsvoorligting in.

In haar werk is die volgende deurlopende doelwitte belangrik:

- om gesondheidsbehoeftes te bepaal;

- om 'n besef van gesondheidsbehoeftes te kweek;

- om beleid wat gesondheid raak te beïnvloed;

- om bemiddelaar te wees vir gesondheidsbevorderende aktiwiteite.

Daar is talle leemtes in die huidige gesinsgesondheidsdiens veral op die gebied van emosionele ondersteuning aan albei ouers in die gesin, die vroeë opsporing van afwykings by kinders en voorkomende en bevorderende gesondheidsdienste aan volwassenes.

\section{INTRODUCTION}

T he range of the community nurse's work in family health care is much wider than that portrayed by the stereotype which many people, both lay and professional, have of it - namely, mother and baby clinics.

The aims of a family health service are:

- to promote good health and to prevent ill-health;

- early detection of ill-health, with prompt and correct referral and treatment;

- disability limitation and rehabilitation

The term family health care is actually a misnomer, since it extends further than the immediate family circle. It encompasses all age groups, individuals without family ties and many fields of health, as listed below.

Maternal and child health, which includes:

- visiting parents and children at home;

- child health clinics, where advice on all aspects of the child is given;

- ante-natal health education;

- developmental assessment and testing of hearing of infants and young children;

- family planning;

- cancer screening such as cytology and breast examination;
- liaison with hospital obstetric and paediatric units.

\section{Control of communicable diseases, including:}

- Tuberculosis control, the cornerstones of which are health education, intensified case-finding, adequate effective treatment and primary protection by B.C.G.

- Venereal disease control based on: health education, case-finding, adequate treatment and follow-up and tracing of contacts.

- Routine Immunisation of infants and immunisation of adults at special risk.

- Health education about the causes, prevention and control of communicable diseases in the home, schools and other institutions.

\section{School health services}

The main aim of this service is to enable children to achieve the maximum benefit from their education by ensuring optimal health. Measures directed towards this aim include periodic medical examinations and health visits, audiometry and visual acuity testing, screening for scoliosis, health education and home visits where necessary.

\section{Occupational health}

As most families have a working member, occupational health contri- butes to family health. It is aimed at establishing and maintaining the highest possible physical and mental well-being of the worker, and so includes:

- pre-employment screening, to assist in placing people in suitable work; - provision of a treatment service;

- control of recognised hazards and identifying unrecognised hazards;

- avoiding potential risks;

- screening for evidence of non-occupational disease;

- supervision of vulnerable groups;

- counselling and health education;

- surveillance of sanitary, catering and welfare facilities;

- environmental control inside and outside of the place of work.

Community psychiatric nursing which includes preventing mental ill health, identifying persons at risk and providing follow-up services for patients receiving psychiatric treatment and their families.

Care of the aged which includes:

- home visiting;

- health assessment and screening for defects;

- clinic sessions;

- recreation facilities;

- medical supervision of the elderly in old age homes.

Health education runs like a thread throughout the whole sphere of the community nurse's work and is per- 
formed continually on a group or individual basis.

\section{THE COMMUNITY NURSE'S FUNCTION}

The content of the community nurse's work will depend on the policies of her employing authority, the organisational and administrative framework in which she works, the size of her caseload and her own aptitudes and interests.

The techniques she uses include observation, interviewing, listening, interpretation, planning, counselling, support, health screening, health teaching, referral and co-ordination.

Her work is based on four important principles:

- the search for health needs;

- stimulation of an awareness of health needs;

- influence on policies affecting health;

- facilitation of health-enhancing activities.

\section{The search for health needs}

The community nurse is the principal case-finding agency of the health care team, being the only professional who routinely visists homes before a crisis has arisen and at a stage where health and social problems may be preventable by her counselling or susceptible to intervention by specialist support.

Primarily, there is a health need where the possiblity of ill-health due to some factor perceived by the community nurse can be foreseen, for example ill-health as a consequence of present behaviour and environmental factors, such as smoking, inconsistant or inadequate child-rearing practices or excessive noise.

Secondly, there is a health need where health is absent, as in illness. Here the community nurse gives moral support to the family as well as practical advice on coping with the problems created by the illness.

Thirdly, there is a health need where a want of health knowledge can be foreseen such as during pregnancy, when motivation and preparation for breast feeding must begin.

Essential factors for a successful search for health needs are:

- to initiate and develop a relationship with the family in such a way that any needs will become apparent and be acknowledged. This requires regular contact, preferably by routine home visiting, so that normal health, any deviation from it and potential health needs may be observed;

- the motivation and ability to initiate the search;
- sound knowledge;

- skill in communication techniques.

From the findings of her search, the community nurse can devise a programme of promotive and preventive health measures for the family and the individual.

Sometimes, needs are apparent immediately and have already created anxiety and family disruption. Basic preventive health measures may not be possible during periods of crisis, but in assisting the family to cope, the community nurse is preventing breakdown. Once the pressure is lessened, the family will be more receptive to guidance on their basic health needs.

\section{Stimulation of the awareness of health needs}

The community nurse fosters an awareness of health needs by health education on a wide variety of relevant topics to individuals and groups on a formal and an informal basis.

For effective health education, the nurse must have a very good knowledge of the families she cares for and be able to identify those persons at particular risk of ill-health.

For example, all people need education about proper nutrition, but high risk target groups include

- very young mothers who may be inexperienced in providing food for themselves and others - especially babies and young children;

- poorly educated mothers who may be unable to interpret the instructions on a tin correctly;

- very large families, where the needs of an individual child may be lost in the crowd;

- poor families who have difficulty in buying the basic necessities of life and where the needs of one person (usually the mother) may be sacrificed to meet the needs of other family members;

- pregnant women:

- premature babies;

- elderly persons living alone;

- those with conditions such as diabetes, malabsorption syndromes, who require special diets;

- children receiving day care (such as with a child-minder) where com. munication breakdown may lead each carer to assume that the child's nutritional needs are being met by the other.

An important point to remember is that parents commonly meet their children's needs unaided but that they may need considerable help in recognising their own. Even when they have re- cognised them, they may need help in meeting them. Some parents may believe that meeting their own needs is a form of indulgence.

This is particularly true of mothers, who may totally submerge their own personalities and interests in their concern for home and family. Short-term sacrifices are tolerable, but the danger of prolonged immersion of self is that the woman may emerge from the childrearing period simply as a pale reflection of her family, with her old interests and friends forgotten.

This does not make for good mental health in middle age, and it is this kind of pitfall which the community nurse must anticipate and try to forestall by encouraging socialisation and development of every family member, including the mother. In so doing she may be helping to reduce divorce, psychiatric illness, alcoholism and child abuse, with their attendant problems.

\section{Influence on policies affecting health}

At a superficial glance, influencing policy does not appear to be the community nurse's role. As a practitioner, however, there are certain areas in which she can and should exert her influence in the interests of the people she serves. For example:

- in the school health field, she should discourage the sale of cariogenic foodstuffs in the tuckshop and press for the opportunity to provide regular health education programmes;

- in the industrial setting, she should attempt to educate employers about those disorders which carry a stigma, such as tuberculosis, alcoholism and epilepsy, and try to persuade them to adopt fair company policies regarding the employment of these people;

- in the child health setting. free samples of baby food are sometimes useful as is educational material provided by the manufacturers. However, each time a free sample is given to a mother the nurse is endorsing its use, even if she does not intend to. In a low socio-economic area this practice could be dangerous, since the mother is tempted to water feeds down to make them last longer.

The community nurse would therefore be wise to adopt a policy of strenuously promoting breastfeeding in the ante-natal period and giving much support and advice in the post-natal period rather than allowing indiscriminate handouts of free baby milk at the clinic. 


\section{Facilitation of health-enhanc- ing activities}

The facilitating and enabling aspect of community nursing can be seen to operate at two distinct levels

At client and family level, the community nurse seeks to facilitate some activity or behaviour change desired in or by the clients or family in order to prevent ill-health.

For example, a mother may be concerned because the baby is fretful, failing to thrive and suffering from frequent bouts of gastro-enteritis. Enquiry into the mother's practices in making feeds and observation of the hygiene of the equipment used may necessitate a demonstration in the mother's own home. The nurse demonstrates how to make up an appropriate feed for the baby and how to clean and sterilise the equipment, while at the same time explaining the importance of each.

As a result, the community nurse will hopefully have enabled the mother to act appropriately in this area, to the benefit of her baby, herself and the rest of the family.

This facilitating aspect of the nurse's work is vital, since many hospital admissions of sick children. and indeed of adults, are a direct result of bad health practices at home.

In this technological era of pseudo-scientific jargon, it is very easy to undervalue simplicity. In the above example, the disruption of family life due to the simple factor of a fretful sickly baby could result in lack of sleep, irritability, strained inter-family relationships, poor time-keeping at work and school, or neglect of siblings, just to mention a few possibilities.

The community nurse cannot take the problems and responsibilities of her families on her own shoulders; she must guide and enable them to solve their own problems.

The second facilitating aspect of community nursing acts at colleague level, where the intention is to facilitate planned activity within the health and related teams for the benefit of the client and family. This intention is achieved through communication, co-operation and referral.

An illustration of this point may be the teamwork necessary in the care of a family with a member suffering from tuberculosis. The team may include nurses, doctors, social workers, employers, school teachers, health educators, laboratory and radiography personnel and voluntary organisations such as S.A.N.T.A. The community nurse, through her knowledge of the family, is in a prime position to facilitate and co-ordinate the work of the team members for the benefit of the family.

Knowledge of the community in which she works is essential for the community nurse. She must be aware of all available community resources, their adequacy, their relevance to the particular community and the reasons, if any, which prevent people from using them.

Where resources are lacking the community nurse should be instrumental in encouraging their provision, with the help of her employing authority, voluntary organisations and the community itself. Examples of such resources are playgroups, mother's groups, old people's clubs and breast-feeding support groups.

Using her skill as an enabler the community nurse should ensure that the bulk of the organisation, administration and support-giving in such groups is eventually done by the members themselves, herself being in the background in an advisory capacity.

This particular principle also covers two other important aspects which are:

- Anticipatory guidance, which involves establishing positive attitudes towards and relevant knowledge of a particular event long before it arises. Such events are, for example, the birth of a baby, the admission of a child to school or hospital, retirement and the eventual death of a family member with a terminal illness.

- Practical demonstration and support. Actions often speak louder than words - for example, parents need to be shown how to stimulate their children and which toys to choose for the various stages of development. This is especially relevant in the case of a handicapped child who requires extra stimulation. Indeed, this is one of the tangible contributions the community nurse can make to such a family in a situation where she sometimes feels that words alone are inadequate.

It must be borne in mind that it is a slow, uphill climb for the community nurse to gain the confidence of the families in her care, and this must be done before she can even begin to think about active intervention. Sadly, the nurse must also appreciate that many of the most seriously disadvantaged never become receptive to the idea of improving their lifestyle. It is often those families who are most in need of continuing support who are hostile, unco-operative and uncommunicative.

Experience teaches the community nurse the value of sharing her concern for such families with colleagues, who, being apart from the situation, are often able to contribute objective insights and ideas for a more effective approach to the problem. Since stable family life is the basis of a sound society, it is important not to give up too soon.

\section{A FAMILY HEALTH SYSTEM OR A FAMILY HEALTH SERVICE?}

A family health care system exists in South Africa, but in some instances it is not being translated into a family health service. A system is defined as a group of parts working together in a regular relationship in contrast to a service which is an arrangement that supplies public needs. At the present needs are not being fully met, especially in some areas of parental health, child health and adult health

\section{Parental health}

Many community nurses would agree that one of their main roles is to provide support for young parents. It is suggested that very little support is in fact provided on a regular and constructive basis and that what is provided is aimed at young mothers and not at young parents.

Where a comprehensive health service is in operation, it is relatively easy for community nurses to be in contact with mothers during the ante-natal period, but in most local authority settings, the community nurse contributes little or nothing to ante-natal care. It is known that prospective parents are particularly receptive to health teaching an opportunity which is not being exploited by the community nurse. The chance to create a relationship with the mother that will make it much easier for the community nurse to offer advice and support in the post-natal period, is being lost.

Factual knowledge about pregnancy and childbirth is very relevant in the antenatal period and readily available, but scant attention is often paid to the feelings and needs of the individual woman. When pregnant women are asked at clinic How are you feeling? it usually relates to the physical symptoms of her pregnancy. Rarely does it mean: how are you feeling about being pregnant, about becoming a mother, 
about your husband or boyfriend becoming a father or your own expectations of this event? It should, but it does not, and here the community nurse has an important role to play.

There is also rarely any opportunity for fathers to talk about their feelings and fears. A need exists for community nurses to initiate the formation of father groups. In such groups fathers could be encouraged to explore their thoughts and emotions on the subject of fatherhood as well as being educated regarding the more obvious topics such as the physical and psychological aspects of pregnancy and behaviour, child care and development. By means of discussion, fathers find mutual support and are more readily able to identify their role as husbands and fathers. By encouraging such groups, the community nurse helps to ensure that a favourable family environment is created before the baby is born. This environment must be maintained and developed by regular visits, support and advice.

Very young parents have special needs. A pregnancy can put enormous pressure on couples who are just learning to live with each other. The pregnancy is often unplanned, finances are strained and housing may be a problem. On top of this a baby is born to a sometimes immature couple at an immature stage of their relationship. Community nurses should provide a counselling service for both parents to help them through this difficult time together.

Community nurses often avoid such involvement because they feel illequipped to help. Until we accept the fact that such involvement is part of our supportive role and that we must learn and cultivate counselling techniques and not be afraid to use them, we will continue to shy away from providing young parents with the help they need. If the community nurse is the one in whom parents confide their problems it is wrong for her to seemingly reject them by referring them to another agency, unless it is the type of problem with which she is not qualified to deal.

Frequently, standard advice on the purely clinical aspects of maternal and child health is given without taking into account the differing circumstances and needs of the people who are being advised. Advice can only be tailored to the client's needs if the community nurse has a thorough knowledge of the home background.

Over the years, the number of single parent families has increased dramatically and young, single parents have particular problems. These parents experience more loneliness, iso- lation and tensions. Community nurses can encourage single parents in their areas to form structured and supportive self-help groups. In such groups, parents should be able to give and receive help with all types of problems, from the purely practical to those of a more emotional nature.

The number of schoolgirl pregnancies is rising yearly, with the average age of the mother becoming progressively lower. The community nurse should become involved in this tense situation as early as possible since she can be an invaluable go-between. Not only should she advise and support the young girl who is pregnant, but also her parents, who may be shocked, angry, disgusted and often unable to think or act rationally or constructively. Frequently, the girl's self-image is under considerable attack by what is happening to her. The community nurse can help her to be as confident and capable as possible in coping with the demands of pregnancy and the decisions about her baby's future whilst she herself is still growing up. Practical assistance such as referral to an antenatal clinic and liaison with the school is necessary, as well as liaison with social workers if adoption is being contemplated. After delivery, follow-up by the community nurse is essential whether the girl keeps her baby or not. In reality, especially if the baby is placed for adoption, the community nurse has little or no contact with unmarried mothers.

\section{Child health}

Community nurses claim that early detection of disease or abnormality is one of their functions, yet many show a curious reluctance to involve themselves in specific activities such as developmental assessment of infants. Although community nurses are trained to assess the development of infants, frequently cited reasons for not doing so are:

- costs, in terms of time and money; - it is the doctor's function;

- it is possible to tell by observation only whether the baby is normal;

- it provokes anxiety in the parents.

Regarding the first statement, developmental assessment takes very little time once the skills have been mastered. The simple equipment needed costs around R20. Additional staff is not necessary, since developmental assessment should be part of the overall service offered by the community nurse to her families. It is done either at home or in the clinic, whichever is the most convenient.

Nurses must recognize that they have independent functions which they per- form in their own right. The second statement reveals a reluctance on the part of the community nurse to assert her professional status and capabilities. Her knowledge of her families and her training eminently equips the community nurse to undertake developmental assessment procedures.

The third statement is only a halftruth. A structured and detailed assessment of the infant in the areas of gross motor function, vision and fine movement, hearing and language as well as social behaviour and play is necessary to detect the more subtle deviations from normal. Developmental assessment is not just secondary prevention, but also includes health promotion, since the parents' interest in the child is increased.

Lastly, if developmental assessment provokes anxiety in the parents, it is because the community nurse is approaching the parents and the procedure incorrectly. Primarily, it should be used as a teaching situation for the parents and secondarily to detect any deviation from the normal for timely and appropriate referral. Since most children are perfectly normal, it is feasible that the second aspect should be played down as far as the parents are concerned.

Developmental problems of many babies are still being diagnosed far too late, losing valuable time before remedial therapy is instituted. This minimises the chances of such a child achieving its maximal potential.

The policy of most local authorities is to provide health services for children up to the age of two years. In practice, this service often stops once the child has been weaned and immunisation completed. This situation reinforces the public's belief that after two years of age the child is no longer vulnerable. In fact, the child is at risk with regard to parental mismanagement because of a breakdown in education about the average characteristics of toddlers. This has implications for the future social and emotional health of the child as certain crucial aspects such as speech are still developing at this age. Problems could go undetected so that the child reaches school-going age with a serious disadvantage.

Present school health services offer a child-centred service, dealing mainly with problems after they have arisen. The promotive and preventive aspects of school health need to be emphasised, with greater attention being paid to the family as a whole. Until caseloads reach a manageable size, this problem will continue to exist. 


\section{Adult Health}

Apart from those workers employed in work situations with a full occupational health service, women who attend antenatal or family planning clinics and the aged attending geriatric clinics, very few promotive and preventive health services are offered to the adult population. There is a need for further investigation into the health problems of adults within the community to highlight specific prevalent conditions. The feasibility of counselling and screening services for these conditions could then be established.

\section{CONCLUSION}

Preventive medicine may sound dull to some. The rewards are not obvious and the role of the community nurse may seem undramatic and lacking any real achievement. So how does she gain work-satisfaction?

People matter. Perhaps this may seem an unnecessary statement to anyone in the caring professions. The practice of community nursing essentially involves building relationships, whether with clients or colleagues. The outcome of all that is done in the various spheres of the community nurse's work depends on the success of this building process.

\section{REFERENCES}

1. An Investigation into the Principles of Health Visiting Council for the Education and Training of Health Visitors - 1977 .

2. Cowper-Smith. F Changes in health visiting. Part 1 and Part 2. Nursing Times. Vol 75 No 15 and 16. A pril 12 and 19. 1979

3. Through the eyes of a child. Nursing Mirror. Special issue for health visitors. Vol 149 No 16. Oct. 181979.

A child health service or a child health system? Community Medicine. London. 1978

5. Schilling, R.H.F.(Ed) Occupational health practice. But terworth. London. 1980

\section{BOOK REVIEW BOEKRESENSIE}

\section{LIVING WITH HIGH BLOOD PRESSURE}

\author{
By Martin Bates \\ Granada Publishing. London. 1980.
}

This is an informative little hardbacked book suitable as a guide for patients and the general public.

It contains non-technical explanations of the causes, signs and symptoms and treatment of hypertension with an appendix giving exercises and diet which the author has found helpful.

Ideal for rehabilitation of the hypertensive and for prevention of some of the predisposing causes, this book would be best placed in waiting rooms and on public library shelves.

V.H.

\section{HEART ATTACK}

\section{Deur lan Anderson \\ MacMillan. 1980. Prys ongeveer R14,20.}

Hierdie is ' $n$ maklik leesbare boek waarin die skrywer grotendeels daarop mik om aan die publiek 'n beeld te stel van wat isgemiese hartsiekte behels. Die boek kan dien as ' $n$ aanmoediging om die insidensie van koronêre trombose te verminder.

Die skrywer gebruik eenvoudige taal en verduidelik die anatomie van die hart en wat met die hart verkeerd kan gaan. Deeglike beskrywings van die risikofaktore word gegee. Verder word opname in " $n$ hospitaal na 'n infarksie, veral ten opsigte van ondersoeke en apparaat, bespreek. Die boek eindig met die rehabilitasie tydperk.

Hierdie boek behoort onder jong mense in skole, kolleges en universiteite versprei te word.

\section{UNDERSTANDING CRIB DEATH}

\author{
by Robert Steele \\ Canadian Public Health Association. Ottawa. 1980.
}

Ek stem heelhartig met Dr. Steele saam dat vermeerdering van kennis deur middel van voortdurende navorsing die probleem van SIDS (Sudden Infant Death Syndrome) kan oplos.

Gewoonlik is ons net bewus van geïsoleerde gevalle van SIDS. Die feit dat in die V.S.A. 25000 tot 30000 en in Kanada 2500 babas elke jaar sterf as gevolg van SIDS is dus insiggewend en bevestig die noodsaaklikheid dat alle verpleegkundiges 'n studie van hierdie onderwerp behoort te maak. Hicrdie boek is uiters geskik vir dié doel en sal 'n aanwins wees in alle biblioteke waar verpleegkundiges naslaanwerk doen en ook in persoonlike boekversamelings.

C.E. VAN NIEKERK

\section{BABY AND CHILD CARE HANDBOOK}

\section{deur Marina Petropulos.}

C. Struik. Cape Town. 1980

Dit was inderdaad 'n voorreg om die boek bestuderend deur te werk. Dit lees maklik en die onderwerpe word in detail uiteengesit.

Vaders en moeders het nou 'n boek waarin hulle inligting in verband met hulle baba asook kleuterprobleme kan naslaan. Die volledige inhoudsopgawe voorsien uitstekend in die doel om naslaan te vergemaklik.

Hierdie boek sal beslis ' $n$ aanwins wees in verpleegbiblioteke en sal 'n waardevolle toevoeging tot persoonlike boekversamelings van verpleegkundiges wees.

Die skryfster van hierdie werk kan verseker wees dat sy, deur haar boek, in die toekoms hulp en sekuriteit aan baie ouers en kinders sal bring. 